\title{
Use of R-WUK pressure suits in the therapy of patients with autism and Asperger syndrome: a preliminary report
}

\author{
Wykorzystanie kombinezonów R-WUK w terapii pacjentów z autyzmem \\ i zespołem Aspergera - raport wstępny
}

\author{
1 Neures Polska, Warsaw, Poland \\ ${ }^{2}$ Department of Occupational and Organisational Psychology, School of Psychology, Cardinal Stefan Wyszynski University, Warsaw, Poland \\ ${ }^{3}$ Department of Simulator Studies for Academic and Practical Aviation Physiology Training, Military Institute of Aviation Medicine, Warsaw, Poland \\ ${ }^{4}$ Department of Paediatrics, Paediatric Nephrology and Allergology, Military Institute of Medicine, Warsaw, Poland \\ Correspondence: Maciej Abakumow, Neures Polska, Mrówcza 165, 04-768 Warsaw, Poland, e-mail: rehabilitacja@neures.pl
}

\begin{abstract}
Pressure suits are used primarily to protect a pilot against increased G-forces and adverse effects of atmospheric pressure at high altitudes. However, pressure suits can also potentially be used for kinesitherapy in patients with orthopaedic, neurological and cognitive deficits, including in those with Asperger syndrome or autism. For this reason, pressure suits have been adapted for therapeutic purposes (rehabilitation). These suits have been named R-WUK. Results obtained in a pilot group show additional possibilities for the application of R-WUK suits in autism therapy and provide a different perspective on the problem of autism spectrum disorder therapy. The innovativeness of this approach is based on the fact that it does not involve any psychological, educational or pharmacological therapies; instead, it employs kinesitherapy with a system that primarily creates physical effects: the suit exerts pressure on the patient's tissues using pneumatic mechanisms. The present approach also involves the use of physiotherapy methods such as PNF, NDT/Bobath and Stand\&Go. As a result of the study intervention, significant changes were observed in the patients' functioning and behaviour. The changes were so significant that it can be concluded that patients who have undergone R-WUK suit therapy function as neurotypical individuals. A low number of subjects in the study group does not allow one to make a definitive determination that all individuals with autism or Asperger syndrome will undergo similar changes in functioning as a result of the suit therapy.
\end{abstract}

Keywords: suit, kinesitherapy, autism, Asperger syndrome, autism therapy

Streszczenie Wysokościowe ubiory kompensacyjne są przeznaczone przede wszystkim do ochrony przed zwiększonymi parametrami przeciążenia, jak również negatywnym oddziaływaniem ciśnienia atmosferycznego na dużych wysokościach na organizm pilota. Jednak innym ich możliwym zastosowaniem jest wykorzystanie w procesie kinezyterapii u pacjentów z deficytami ortopedycznymi, neurologicznymi i poznawczymi, w tym w terapii pacjentów z zespołem Aspergera lub autyzmem. $\mathrm{Z}$ tego względu wysokościowe ubiory kompensacyjne zostały zaadaptowane do celów terapeutycznych (rehabilitacyjnych) i otrzymały nazwę R-WUK. Uzyskane wyniki badań przeprowadzonych w grupie pilotażowej pokazują dodatkowe możliwości zastosowania kombinezonów R-WUK w terapii autyzmu oraz umożliwiają odmienne spojrzenie na problematykę terapii zaburzeń ze spektrum autyzmu. Innowacyjne podejście w tym wypadku polega na odejściu od terapii psychologicznych, pedagogicznych czy też farmakologicznych na rzecz kinezyterapii prowadzonej przy użyciu systemu, którego kluczowy mechanizm polega na stworzeniu oddziaływań fizykalnych (nacisku wywieranego na tkanki przez kombinezon), powodujących odpowiednie naciski ubioru przy wykorzystaniu pneumatyki oraz metod fizjoterapeutycznych, takich jak PNF, NDT Bobath czy Stand\&Go. W wyniku przeprowadzonych badań u pacjentów zaobserwowano istotne zmiany $\mathrm{w}$ funkcjonowaniu i zachowaniu. Zmiany te były na tyle ważne, że upoważniają do stwierdzenia, że pacjenci poddani terapii w kombinezonach R-WUK funkcjonują jako osoby neurotypowe. Z uwagi na małą liczebność grupy badanej trudno stwierdzić jednoznacznie, czy u wszystkich osób z autyzmem lub zespołem Aspergera oddziaływanie kombinezonów będzie powodować podobne zmiany w funkcjonowaniu.

Słowa kluczowe: kombinezon, kinezyterapia, autyzm, zespół Aspergera, terapia autyzmu 


\section{INTRODUCTION}

$\mathrm{T}$ he systematically rising number of newly diagnosed cases of autism spectrum disorder (ASD) ${ }^{(1)}$ is associated with challenges in terms of the need to develop more precise diagnostic criteria and better therapeutic methods. ASDs are relatively common. Based on recent research, it is estimated that the prevalence of classic autism (typical communication and social interaction impairment combined with restricted, stereotypical behaviour) is 30 cases per 10,000 individuals and the prevalence of ASD is as high as 1 case per 100 individuals ${ }^{(2)}$. According to research of 1960s and 1970s, the rate of autism and related disorders was 5-15 children per 10,000 births at the time. Currently, studies conducted in countries where diagnostic and statistical methods are well developed estimate the prevalence of autism and autism spectrum disorders to be $30-60$ cases per 10,000 individuals ${ }^{(3)}$. These disorders are 3-4 times more frequent among boys than girls with the predominance of males rising among high-functioning adults. Epidemiological research conducted over the years suggests that the prevalence of the disorders is rising. This is probably due to diagnostic criteria being widened and accommodating cases that were previously classified differently and ASDs being diagnosed more accurately ${ }^{(4)}$. Childhood autism and related ASDs are an increasingly significant health problem. An important diagnostic difficulty associated with suspected ASD is a lack of distinct aetiology and pathogenesis focused on a single significant cause. What is worse, none of the currently proposed causes of ASD is exhaustive. Current research efforts focus on the identification of the effects of autism, earlier detection of ASD cases and the use of increasingly better diagnostic tools. As a result, quicker and more effective intervention is possible to substantially mitigate the consequences of the disorder. The current understanding of autism is that it is a psychogenic disorder which is a child's response to an adverse environment. Medical and psychological observation of a child's development plays a very important role. It begins already during foetal development and takes into account consecutive phases of the evolution of awareness, from a primitive stage all the way to the emergence of a sense of self in relation to others in the surrounding environment. Other cognitive, behavioural and emotional mechanisms that underlie normal development are also analysed $^{(2)}$. Jean Ayres presents a somewhat different approach. She believes that ASD symptoms are a consequence of impaired sensory integration manifesting as dysfunctional organisation and coordination of processing of sensory stimuli ${ }^{(5)}$. This cognitive process dysfunction results in the inability of the nervous system to accurately organise information coming through different sensory channels. For this reason, an individual is not able to integrate the incoming data and connect them in a meaningful way with previous information. This leads to an inadequate reaction to a specific stimulus appearing at a given moment.
Autism is usually diagnosed based on two classifications: Diagnostic and Statistical Manual of Mental Disorders, $5^{\text {th }}$ edition (DSM-5) and International Classification of Diseases, $10^{\text {th }}$ revision (ICD-10). DSM-5 contains three most important diagnostic criteria for autism:

1. clinically significant impairment in social communication and interaction;

2. restricted, repetitive patterns of behaviour, interests and activity;

3. onset of symptoms in early childhood (but they may not become fully apparent until social expectations exceed the child's limited abilities) ${ }^{(6)}$.

In DSM-5, the term "pervasive developmental disorder" was replaced with "autism spectrum disorder," which means that apart from autism, there may exist other, not fully diagnosed conditions, including Asperger syndrome, which is different from ASD in that individuals with Asperger syndrome find it easier to communicate with other people and do not display any distinct developmental delays. A three-level classification is used to characterise these conditions. ICD-10 includes the following major manifestations of autism:

1. severe social behaviour and interaction impairment;

2. severely impaired communication development (including delayed speech development);

3. rigid and restricted repertoire of behaviour, routine.

The ICD-10 classification was introduced in 1992 (WHO, 1992) and reflects the understanding of autism at the time, including the treatment of Asperger syndrome as a separate subtype of autism. DSM-5, which was introduced in 2013, removes Asperger syndrome as a separate subtype of autism. Both DSM-5 and ICD-10 include the consideration whether the symptoms found in an individual sufficiently impair their functioning in everyday life. This involves a certain degree of diagnostic flexibility: mild problems with social communication and slightly repetitive behaviour and interests may not be burdensome enough to warrant a diagnosis ${ }^{(7-9)}$.

\section{MATERIALS AND METHODS}

The methodology of the present study was designed so as to verify the assumption that the pressure exerted by an R-WUK suit on the soft tissues of a subject leads to an increased influence of proprioceptive processes on the sensation of their body, thus improving their global sensory functioning and changing their brain activity.

The study methodology involved the use of the following psychological tests: Autism-Spectrum Quotient (AQ) and Autism Spectrum Rating Scales (ASRS) before and after the suit therapy. Before the start of the therapeutic sessions, a suit size was selected to match the patient's height. After that, blood pressure, heart rate and oxygen saturation level were measured. Subsequently, the patient performed exercises in an R-WUK suit (Fig. 1). The exercises were based on therapeutic methods such as proprioceptive 


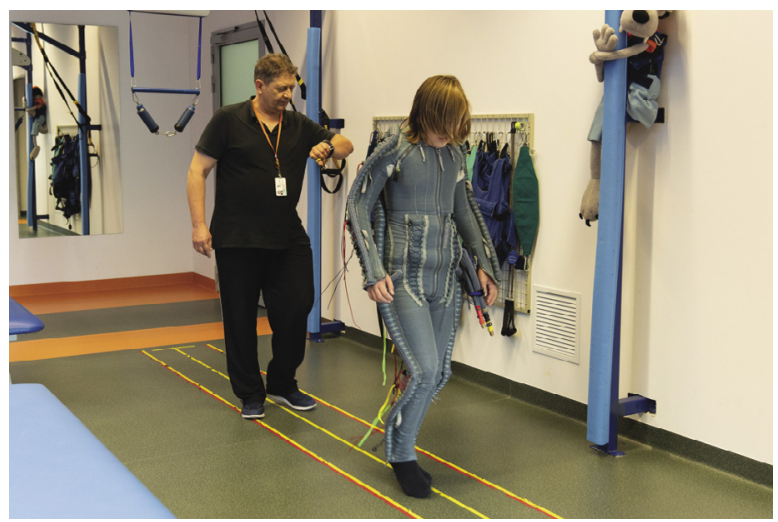

Fig. 1. Exercise sessions in an R-WUK suit (the patient's consent was obtained for the photograph)

neuromuscular facilitation (PNF) and neuro-developmental treatment (NDT)/Bobath concept ${ }^{(10-12)}$. They aimed to improve the subject's hand-eye coordination and to provide them with balance training, breathing exercises and movement practice in intermediate positions (positions between high ones such as standing and low ones such as crawling). Within 5 minutes of the end of an exercise session, blood pressure, heart rate and saturation were measured again. After a 10-session cycle was completed, AQ and ASRS tests were administered again.

The current study was divided into two stages and included 4 children aged $12-15$ years. The first stage involved the study of 1 child according to the R-WUK suit therapy methodology. Previous research demonstrated that this therapy is safe for a patient ${ }^{(13)}$. Before the therapy, the patient was also evaluated to determine the baseline state which would serve as a point of reference for further analysis. To this end, in the case of 1 child, a decision was made to use the AQ test ${ }^{(8,14)}$, which includes 13 categories of behaviour: 1) interpersonal relations, 2) mimicry/imitation, 3) emotional response, 4) body control/body use, 5) use of objects, 6) adaptation/adjustment to change, 7) visual responses, 8) auditory responses, 9) use of taste, smell and touch, 10) fear/anxiety and nervousness, 11) verbal communication, 12) non-verbal communication, 13) level of activity. There is also a separate category of general impression. The AQ test includes four variants: "I definitely agree," "I agree," "I disagree" and "I definitely disagree." Regardless of the actual wording of the answers, those which confirmed autistic traits were awarded 1 point and are referred to as positive answers. Answers which excluded autistic traits were awarded 0 points and are referred to as negative answers $^{(15,16)}$. This test aimed to determine whether and to what extent the use of R-WUK suits would change and improve psychological and social functioning of the patient. Additional verification was also requested such as:

- opinion of the patient's schoolteacher;

- opinion of the attending physician (neurologist, psychiatrist);
The study took 3 months and involved 10 sessions of up to 60 minutes. The study received the approval of the Ethics Committee for Biomedical Research at the Military Institute of Aviation Medicine in Warsaw (approval No. 13/2015 and $3 / 2017$ ). The researchers focused on the following fundamental aspects:

1. gross and fine motor skills;

2. sense of balance;

3. breathing quality;

4. control of psychological and social functions.

Based on earlier observations, the researchers assumed that aspects 1-3 would improve to a substantial extent as a result of the suit therapy; as for point 4 , no expectations were made due to the fact that improvement in this respect is definitely the most difficult problem in individuals with symptoms of ASD.

The results obtained on the AQ test and positive of opinions of the attending physician and of the school encouraged the researchers to conduct another study with the use of R-WUK suits.

During stage 2 of the study, the researchers focused on patients with a valid certificate stating that they have autism. In order to obtain more credible data, age-appropriate (6-18 years) ASRS by Goldstein and Naglieri were used. An additional factor which serves as a filter in ASRS is statistical significance determined based on T-scores. The test itself assumes that parental answers need to be statistically significant at $p=0.05$, while the teacher's input needs to be at $p=0.01^{(17)}$. At stage 2 of the study, an identical protocol was used to that for the patient from stage 1 except for the fact that the subjects were administered ASRS instead of AQ before and after R-WUK suit therapy. The therapeutic process also included 10 sessions performed according to the methodology used previously. In order to introduce additional verification, a teacher ASRS test was used alongside parental ASRS. A decision was also made to extend the pilot group to 3 individuals: 2 boys aged 12 and 1 girl aged 15 years.

On ASRS, the patient was assessed in the following categories: TS - total score, SRC - social relations/communication, AB - atypical behaviour, SR - self-regulation, DSM general disorder scale and on 8 therapeutic scales: RP - relations with peers, RA - relations with adults, SER - social and emotional reciprocity, AL - atypical language, ST stereotypies, RB - rigid behaviour, $\mathrm{SS}$ - sensory sensitivity, AT - attention.

\section{RESULTS}

According to the results obtained in stage 1 of the study, before therapy, the subject scored 42 points on the AQ screening test, which indicated the presence of autism spectrum symptoms. However, after a cycle of 10 exercise sessions, the score was 15 points, which classified the patient as being not on the autism spectrum. Based on the test results, one may conclude that the influence of R-WUK suits is beneficial to patients. 


\section{Test AQ - Autism-Spectrum Quotient}

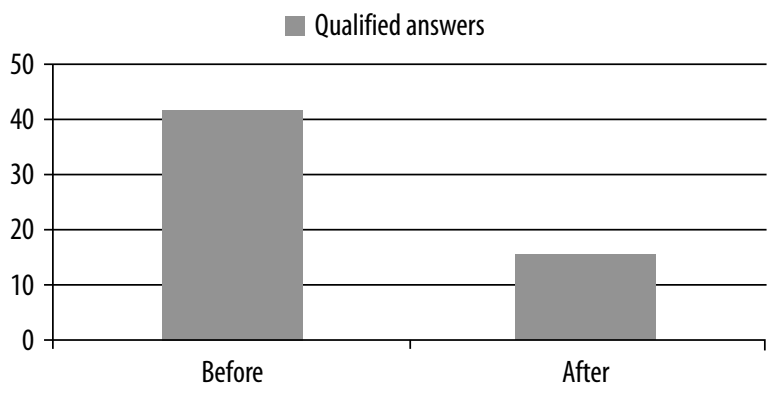

Fig. 2. AQ testing in the patient: before - baseline score, after final score (norm: 29 points)

The results obtained on AQ are presented in Fig. 2.

In order to make closer observations of changes in the subjects, the taxonomy of the test was changed to TAKS-2, which shows to a more significant extent the shift away from the extreme negative answers: every extreme qualified answer („I definitely agree” or „I definitely disagree”) was awarded 2 points. Every regular qualified answer (,I agree” or „I disagree”) was awarded 1 point. As a result, 32 extreme answers scored 64 points. However, the final test showed only one extreme answer, thus the score for extreme answers being only 2 points. The results are presented in Fig. 3 .

In the case of 2 patients (boys), the results of parental and teacher tests demonstrated that the data obtained for both patients were significant. There was only one T-score that could not be considered statistically significant: sensory sensitivity for the first patient and atypical language for the second one. TS (total score) and DSM (general disorder scale) were similar for the two patients in that both parental and teacher ASRS scores achieved an average level, which should be interpreted as indicating no autistic traits according to the authors of the test. Based on the test results, the R-WUK suit therapy can be considered to have caused improvement in the boys' functioning.

The subjects' test results are presented in Figs. 4 and 5. In the case of the female patient, the final results did not differ in terms of statistical significance from baseline, although individual results for 3 scales that were significant could be considered promising, which encourages further research (Fig. 6).

\section{TAKS-2}

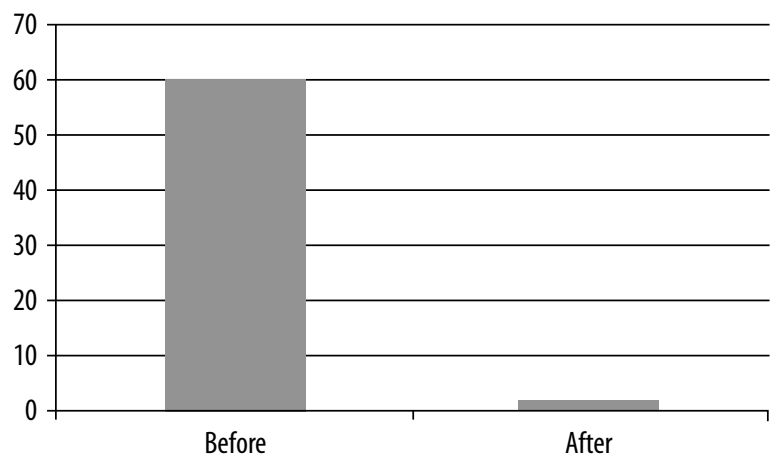

Fig. 3. TAKS-2 - scores on Autism-Spectrum Quotient (AQ)
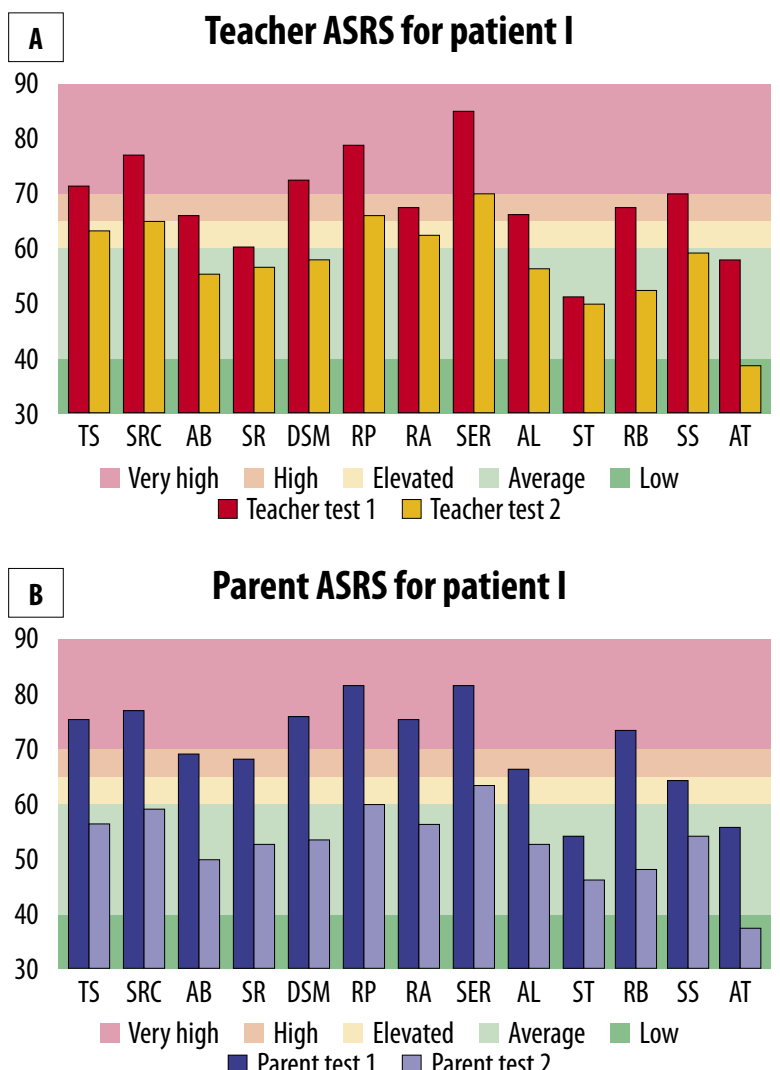

Fig. 4 A, B. ASRS (Autism Spectrum Rating Scales) scores for the first patient (I)

However, during suit therapy, the female patient was found to experience decreased oxygen saturation. This was reported in a separate article ${ }^{(18)}$. The T-scores do not provide evidence for any significant changes in the psychological and social functioning of the girl as a result of the suit therapy. One may assume with a high degree of probability that prolonged oxygen deficits could have been an important cause of the lack of desired therapeutic effects.

\section{DISCUSSION}

The search for new methods, techniques and equipment for the therapy of patients with ASD is currently becoming an ever more important task considering the dynamics of diagnostic possibilities and an increased rate of newly diagnosed ASD cases. At the same time, autism classification is being changed ${ }^{(7)}$. Therapeutic management can be divided into psychoanalysis-related therapies such as holding therapy or psychotherapy, and medical therapies such as special diets, supplementation or chelation treatment ${ }^{(14)}$. However, all of these therapies are long-term interventions which are not always effective. It was hyperbaric oxygen therapy, which is a medical therapy, that produced definitely the most beneficial therapeutic effects ${ }^{(19)}$. However, the results are neither satisfactory themselves nor in comparison to the costs ${ }^{(20)}$. In addition, the European Underwater and Baromedical Society, the 

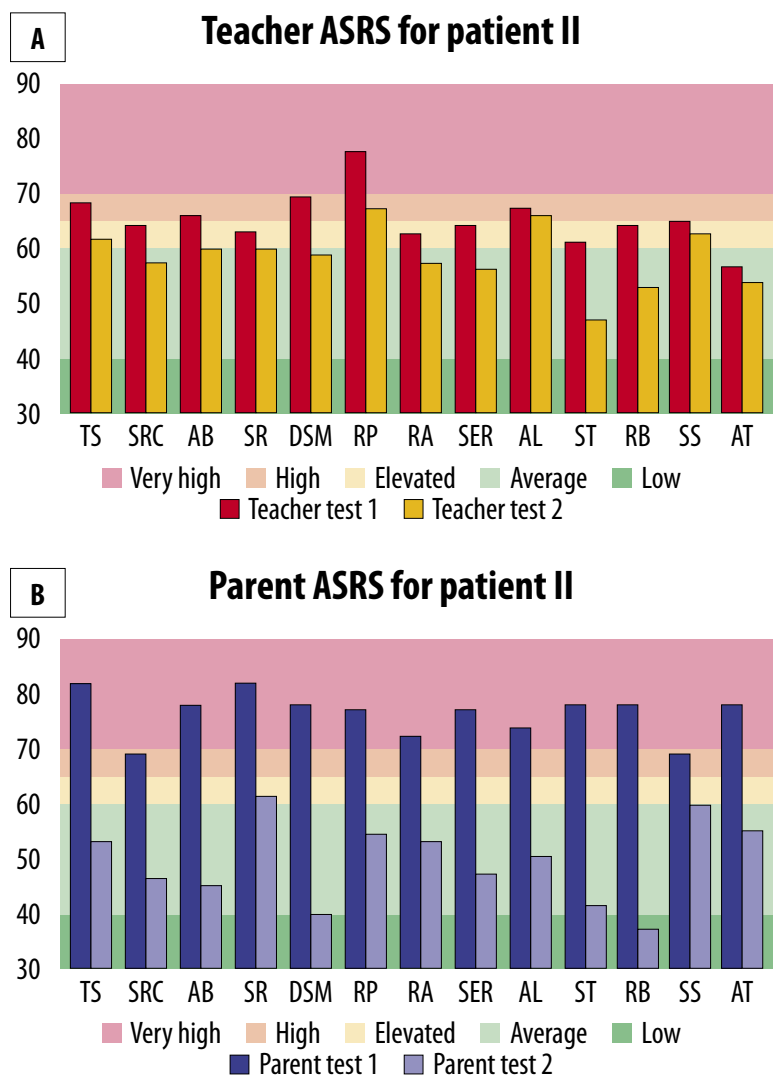

Fig. 5 A, B. ASRS (Autism Spectrum Rating Scales) scores for the second patient (II)

U.S. Food and Drug Administration and the Undersea and Hyperbaric Medical Society have not acknowledged ASD as an indication for hyperbaric oxygen therapy. The European Underwater and Baromedical Society published a position paper in "Diving and Hyperbaric Medicine" stating definitively that autism should not be an indication for hyperbaric oxygen therapy ${ }^{(21,22)}$.

Based on this preliminary study one may assume that the use of R-WUK suits provides promising therapeutic effects. The very short duration of the therapy is an important factor, since it is associated with lower costs compared to other therapies. This may point to a new direction in the therapy of autism and Asperger syndrome patients who experience impaired cerebral analysis of stimuli reflected in their psychosocial relations. However, one needs to bear in mind that these results are only preliminary and do not necessarily have to translate into outcomes in a much larger group of subjects. The current study included only a limited number of patients with ASD in whom exercises using R-WUK suits were found to have a beneficial impact with the absence of adverse effects, which is important in the context of any existing comorbidities. The initial hypothesis regarding a mechanism which causes all receptors to stabilise through improved proprioception, thus altering the patient's perception and psychosocial relations, is insufficient and will need to be verified in further research on a larger
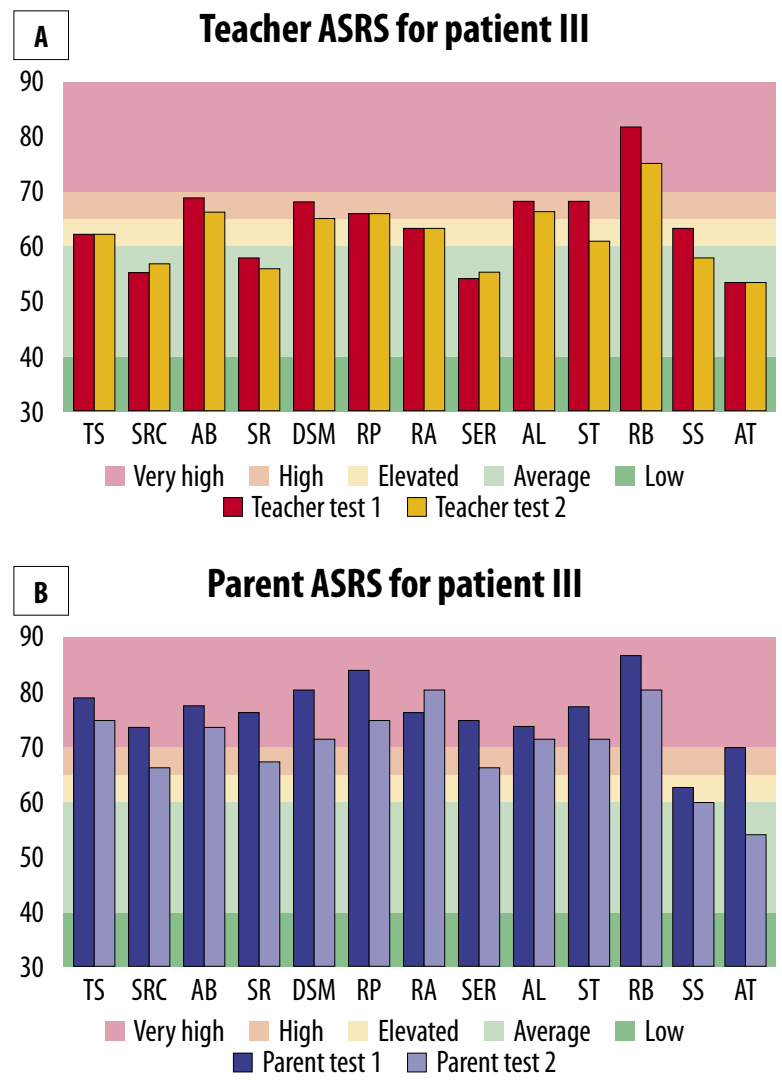

Fig. 6 A, B. ASRS (Autism Spectrum Rating Scales) scores for the female patient (III)

\section{Conflict of interest}

The authors do not report any financial or personal affiliations to persons or organisations that could adversely affect the content of or claim to have rights to this publication.

\section{References}

1. Wroniszewski M, Grochowska J: Wczesna intensywna interwencja w autyzmie dziecięcym. In: Serafin T (ed.): Wczesne wspomaganie rozwoju dziecka od chwili wykrycia niepełnosprawności do podjęcia nauki w szkole. Poradnik dla organizatorów działań, dla terapeutów oraz dla rodziców. Ministerstwo Edukacji Narodowej i Sportu, Warszawa 2005: 133-150.

2. Jagielska G: Etiologia zaburzeń autystycznych. In: Komender J, Jagielska G, Bryńska A (eds.): Autyzm i zespół Aspergera. Wydawnictwo lekarskie PZWL, Warszawa 2009.

3. Pisula E: Małe dziecko $\mathrm{z}$ autyzmem. Gdańskie Wydawnictwo Psychologiczne, Gdańsk 2005.

4. Pisula E: Autyzm u dzieci. Diagnoza, klasyfikacja, etiologia. Wydawnictwo Naukowe PWN, Warszawa 2002.

5. Szmania L: Etiologia zaburzeń spektrum autyzmu - przegląd koncepcji. Interdyscyplinarne Konteksty Pedagogiki Specjalnej 2015; (11): 93-123.

6. Rynkiewicz A, Kulik M: Wystandaryzowane, interaktywne narzędzia do diagnozy zaburzeń ze spektrum autyzmu a nowe kryteria diagnostyczne DSM-5. Psychiatria 2013; 10: 41-48.

7. World Health Organization: Międzynarodowa statystyczna klasyfikacja chorób i problemów zdrowotnych. Rewizja dziesiąta. Tom I, wydanie 2008, Centrum Systemów Informacyjnych Ochrony Zdrowia, 2012. 
8. Pużyński S, Wciórka J: Klasyfikacja zaburzeń psychicznych i zaburzeń zachowania w ICD-10. Opisy kliniczne i wskazówki diagnostyczne. Uniwersyteckie Wydawnictwo Medyczne „Vesalius", Kraków 2007: 194-214.

9. Łojko D, Suwalska A, Rybakowski J: Dwubiegunowe zaburzenia nastroju i zaburzenia depresyjne w klasyfikacji DSM-5. Psychiatr Pol 2014; 48: 245-260.

10. Mikołajewska E, Mikołajewski D: Metoda Bobath w rehabilitacji dorosłych i dzieci. Niepełnosprawność - zagadnienia, problemy, rozwiązania 2016; (1): 7-24

11. Kowalska-Kantyka M: Stymulacja i rehabilitacja dzieci oraz młodzieży metodą NDT-Bobath. Chowanna 2004; 47: 61-71.

12. Adler SS, Beckers D, Buck M: PNF w praktyce. Ilustrowany przewodnik. $3^{\text {rd }}$ ed., DB Publishing, Warszawa 2009.

13. Abakumow M, Kowalczuk K: Safety of use of high altitude protection suits for kinesitherapy - preliminary report. Pol J Aviat Med Bioeng Psychol 2019; 25: 50-54.

14. Krzysztofik K, Otrębski W: Narzędzia pomiaru nasilenia syndromu autyzmu i wybranych procesów neuropoznawczych u osób z ASD. Psychiatr Pol 2018; 52: 641-650.

15. The AQ Test. Available from: http://psychiatryassociatespc.com/ doc/Autism_Quotient_Test.pdf.

16. AQ Test. Available from: https://aspergerstest.net/aq-test/.

17. Guzik-Kornacka A, Szostakowska S, Żurawska J et al.: Raport $\mathrm{z}$ badań $\mathrm{w}$ ramach projektu multimodalny system do funkcjo- nalnej diagnostyki i wspomagania terapii dzieci z zaburzeniami ze spektrum autyzmu. Fundacja SYNAPSIS, Neuro Device Group, 2019.

18. Abakumow M, Gaździński SP, Kowalczuk K: Initial depression and normalization of higher extremity oxygenation in an autistic girl due to kinesitherapy using an adapted high altitude protection suit: a case study. Pol J Aviat Med Bioeng Psychol 2018; $24 ; 19-22$.

19. Vecchione R, Picariello N, Hassan $\mathrm{H}$ et al.: Low pressure hyperbaric oxygen therapy in autism spectrum disorders: a prospective, randomized study of 30 children. Int J Curr Res 2016; 8: 30587-30598.

20. Rossignol DA, Bradstreet JJ, Van Dyke K et al.: Hyperbaric oxygen treatment in autism spectrum disorders. Med Gas Res 2012; 2: 16.

21. Goldfarb C, Genore L, Hunt C et al.: Hyperbaric oxygen therapy for the treatment of children and youth with Autism Spectrum Disorders: an evidence-based systematic review. Res Autism Spectr Disord 2016; 29-30: 1-7.

22. Bennett M, Hart B: UHMS position paper the treatment of autism spectrum disorder with hyperbaric oxygen therapy. Available from: https://www.uhms.org/images/Position-Statements/autism_position_paper.pdf. 